\title{
Value-Added Compound Recovery from Invasive Forest for Biofunctional Applications: Eucalyptus Species as a Case Study
}

\author{
Patricia Gullón ${ }^{1}$ D , Beatriz Gullón ${ }^{2}$, Gonzalo Astray ${ }^{3,4}$, Paulo E. S. Munekata ${ }^{5}$, \\ Mirian Pateiro ${ }^{5}$ (D) and José Manuel Lorenzo ${ }^{5,6, *(D)}$
}

1 Nutrition and Bromatology Group, Department of Analytical and Food Chemistry, Faculty of Food Science and Technology, University of Vigo, Ourense Campus, 32004 Ourense, Spain; pgullon@uvigo.es

2 Department of Chemical Engineering, Faculty of Science, University of Vigo (Campus Ourense), As Lagoas, 32004 Ourense, Spain; bgullon@uvigo.es

3 Department of Physical Chemistry, Faculty Science, Faculty of Science, University of Vigo (Campus Ourense), As Lagoas, 32004 Ourense, Spain; gastray@uvigo.es

4 CITACA, Agri-Food Research and Transfer Cluster, Campus Auga, University of Vigo, 32004 Ourense, Spain

5 Centro Tecnológico de la Carne de Galicia, Rúa Galicia No 4, Parque Tecnológico de Galicia, San Cibrao das Viñas, 32900 Ourense, Spain; paulosichetti@ceteca.net (P.E.S.M.); mirianpateiro@ceteca.net (M.P.)

6 Área de Tecnología de los Alimentos, Facultad de Ciencias de Ourense, Universidad de Vigo, 32004 Ourense, Spain

* Correspondence: jmlorenzo@ceteca.net; Tel.: +34-988-548-277; Fax: +34-988-548-276

Academic Editors: Daniel Granato and Petri Kilpeläinen

Received: 28 August 2020; Accepted: 14 September 2020; Published: 15 September 2020

\begin{abstract}
From ancient times, the medicinal properties of the different Eucalyptus species are well known. In fact, plants from this family have been used in folk medicine as antiseptics, and to treat different ailments of the upper respiratory tract such as sinus congestion, common cold, or influenza. Moreover, other biological activities were described for Eucalyptus species such as antioxidant and antimicrobial properties. In the last few decades, numerous investigations revealed that the compounds responsible for these properties are secondary metabolites that belonging to the group of phenolic compounds and are present in different parts of the plants such as leaves, bark, wood, fruits, and stumps. The increasing demand for natural compounds that can substitute synthetic antioxidants and the increase in resistance to traditional antibiotics have boosted the intense search for renewable natural sources containing substances with such bioactivities, as well as greener extraction technologies and avant-garde analytical methods for the identification of the target molecules. The literature data used in this paper were collected via Scopus (2001-2020) using the following search terms: Eucalyptus, extraction methods, phenolic compounds, and biological activities. This review collects the main studies related to the recovery of value-added compounds from different Eucalyptus species, as well as their biofunctional applications.
\end{abstract}

Keywords: biomass; innovative extraction technologies; polyphenols; biological properties

\section{Introduction}

In the last few years, there has been an increase in social concern regarding health issues, as well as a trend toward the use of natural compounds, leading to great efforts devoted to the search of new biosources rich in bioactive molecules with beneficial properties for human health and wellbeing [1]. Therefore, the presence of natural products in the pharmaceutical, food processing, and supplement production industries is growing [2]. 
In this context, forest biomass produces secondary metabolites that are bioactive molecules with antibacterial properties and low toxicity, which are considered potential candidates for developing a new generation of antimicrobial agents [3,4]. Since ancient times, several parts of forest biomass have been used to treat or prevent different diseases. This popular use has encouraged an intense investigation to identify secondary biomass metabolites as a source of medicinal agents [5].

In this sense, in the last few years, the growing interest in replacing synthetic antioxidants has fostered research in renewable secondary biomass metabolites to obtain natural and low-cost antioxidants that can substitute synthetic preservatives such as butylated hydroxyanisole (BHA), butylated hydroxytoluene (BHT), and/or propyl gallate and terbutyl hydroquinone (TBHQ) [4,6-8], showing that they present toxic, carcinogenic, and harmful effects on human health. These natural antioxidant compounds have applications in the field of foods by preventing lipid peroxidation, and they can also be used as protective agents against oxidative damage and food-borne spoilage microorganisms [7,9-12]. Moreover, natural antioxidants can be used in topical pharmaceutical and cosmetic compositions [4,13].

The genus Eucalyptus (Myrtaceae family) is indigenous to Australia and encompasses more than 900 species and subspecies [14]. It is an invasive species, which is highly inflammable and responsible for forest fire. Its wood is used in pulp and paper manufacture due to its fast-growing and short rotation periods and excellent properties of pulping and bleaching [15]. Moreover, different species of Eucalyptus are used in folk medicine as antiseptics due to their antimicrobial properties, and to treat respiratory infections (common cold, influenza, and/or sinus congestion) [16]. Furthermore, the essential oils from this genus are well known to display several bioactivities such as antibacterial, antifungal, analgesic, and anti-inflammatory properties [14,17].

In recent years, the different parts of the trees belonging to the Myrtaceae family such as bark, leaves, branches, fruits, and knots have attracted much attention as promising sources of high-value phytochemicals [15]. In particular, Eucalyptus species are excellent sources of bioactive terpenoids, tannins, flavonoids, and phloroglucinol derivatives [18].

An essential aspect in the field of extraction of biomolecules from natural sources is the selection of the more suitable technology, as well as of the solvent, to guarantee a high yield and to maintain the bioactivities of the recovered extract such that, when it is incorporated in a food matrix, it maintains its functionality. In the recent past, the recovery of phytochemicals from natural sources was based on conventional methods that use organic solvents and their aqueous mixtures. Currently, it is known that these methods present drawbacks with negative consequences for the bioactivities of the recovered phytochemicals. Consequently, in recent years, there has been an increase in the development of eco-friendly and sustainable avant-garde technologies combined with smart solvents to preserve the functionality of the extracted compounds. In the last decade, ultrasound-assisted extraction (UAE), microwave-assisted extraction (MAE), supercritical fluid extraction (SFE), and subcritical water extraction (SWE) were outlined as safe and effective technologies in the field of recovery of biomolecules from forest biomass [19-23].

This review collects the studies related to the recovery of phytochemicals from different Eucalyptus species. Aspects such as the main phenols identified in extracts recovered from different parts of the plant belonging to the Eucalyptus species, the different extraction technologies from conventional to innovative employed, and the biofunctional properties assayed until date of the recovered extracts are addressed.

\section{Phenolic Compounds from Eucalyptus Species}

Phenolic compounds are secondary plant metabolites [24] that are present in the plant kingdom [24,25] and are extracted from different parts of plants [26-30].

According to the World Health Organization (WHO), Eucalyptus is reported to have different medicinal uses including as an expectorant or to treat asthma, influenza, diarrhea, and fungal infections, 
among others [2,31]. These compounds can be located in some plants at a high level of content and, due to this fact, these plants have an important role as natural antioxidants [32].

Eucalyptus species contain different important amounts of phenolic compounds which confer the antioxidant activity of their extracts [31,33]. Different phenolic compounds such as ellagic acid, rutin, and quercetin, among others have been isolated from different Eucalyptus extracts [31,33,34], and, according to a research carried out by Santos et al. [15], Eucalyptus species (E. grandis, E. urograndis (E. grandis $\times$ E. urophylla), and E. maidenii) present high potential as good sources of biologically active phenolics.

Almeida et al. [31] studied the phenolic profile of E. globulus leaves using high-performance liquid chromatography (HPLC) with a reversed-phase Spherisorb ODS2 column and a C18 guard column. According to the authors, four phenolic compounds were identified and quantified $(\mathrm{mg} / \mathrm{g}$ of lyophilized extract) in the leaf extracts: flavonoids (rutin 4.4 and quercitrin 2.4) and phenolic acids (chlorogenic acid 4.5 and ellagic acid 2.7). A similar study was carried out by Santos-Ferreira et al. [35] who studied the phenolic compounds in extracts from dried E. globulus leaves. Phenolic compounds were extracted upon mixing the dried leaves with different solvents: chloroform, ethanol, methanol, or methanol/water (70:30, v/v) and then purified using solid-phase extraction (SPE) [35]. The HPLC-MS/MS analysis showed the existence of chlorogenic acid, rutin, and quercetin 3-glucuronide in the purified methanol/water extract, as well as ellagic acid derivatives (dried Eucalyptus leaves) [35].

The phenolic composition of other Eucalyptus species has also been determined. For example, Nasr et al. [36] carried out extractions for five different species of Eucalyptus (E. maidenii, E. robusta, E. citriodora, E. tereticornis, and E. camaldulensis) to compare their content in some primary and secondary metabolites. The authors identified different phenolic compounds, varying their abundance in Eucalyptus leaves, with eight individual phenolics (hydroquinone, hesperitin, pyrogallol, resorcinol, protocatechuic acid, naringenin, chlorogenic acid, and catechin) highlighted in E. camaldulensis leaves and gallic highlighted in E. tereticornis leaves [36]. Another interesting research was carried out by Akamura et al. [34] who tried to elucidate the constituents of a commercial Eucalyptus leaf extract using HPLC and GC/MS. Different phenolic compounds such as gallic acid and ellagic acid were detected and quantified $(1.68 \mathrm{mg} / \mathrm{g}$ and $1.32 \mathrm{mg} / \mathrm{g}$ of Eucalyptus product weight, respectively). Moreover, they also found different mono- and sesquiterpenes, such as 1,8-cineole, $\alpha$-terpineol acetate, aromandendrene, globulol, and sesquiterpene alcohol.

E. globulus leaves were also used by Dezsi et al. [37] to determine their phenolic profile. The ethanolic extracts were analyzed by HPLC/MS, and significant amounts of phenolic compounds were found. The major flavonoid compound was hyperoside $(666.4 \mu \mathrm{g} / \mathrm{g}$ dry weight $(\mathrm{dw})$ plant material), followed by quercitrin $(287.8 \mu \mathrm{g} / \mathrm{g} \mathrm{dw}$ plant material) and myricetin $(92.3 \mu \mathrm{g} / \mathrm{g} \mathrm{dw}$ plant material). Other polyphenols (rutin, isoquercitrin, luteoline, and apigenine, among others) were identified in minor amounts [37].

The extraction of phenolic compounds is also possible from other parts of Eucalyptus, not only from the leaves. In this case, Nasr et al. [38] examined the phenolic profile of four organs from E. camaldulensis using GC/MS, namely, leaves, buds, empty capsules, and seeds. The GC/MS analysis confirmed that the presence of some phenolic compounds varied depending on the part of the plant under investigation. The most abundant phenolic compounds were gallic acid, catechin, and tricetin with relative abundances of $1898.8 \%, 1360.8 \%$, and $1323.8 \%$, which were mainly present in the plant seed compared to the other studied parts. According to the data provided by the authors, generally, the seed showed the highest content for some of the detected compounds including hydroquinone, pyrogallol, and taxifolin, among others, while the leaf presented the greatest abundance of hesperitin, resorcinol, and chlorogenic acid, the bud presented the highest neohesperidin content, and the plant capsule presented the second highest contents of tricetin, gallic acid, and catechin.

Vázquez et al. [39] used matrix-assisted laser desorption ionization time-of-flight (MALDI-TOF) mass spectrometry and reverse-phase high-performance liquid chromatography/electrospray ionization time-of-flight (RP-HPLC-ESI-TOF) mass spectrometry to identify the different phenolic antioxidants 
from E. globulus bark aqueous extracts. This study confirmed the presence of polygalloylglucoses mixtures (gallotannins), catechin, and epicatechin or ellagic acid, among others.

Santos et al. [15] identified the phenolic profile in bark extracts (methanol/water 50:50) of various species: E. grandis, E. maidenii, and E. urograndis (E. grandis $\times$ E. urophylla). Different phenolic compounds were identified for each species (13 for E. grandis, 24 for E. maidenii, and 12 for E. urograndis), with ellagic acid-rhamnoside, dihydroxy-isopropylchromone-hexoside, and dihydroxy-(methylpropyl)isopropylchromone-hexoside referenced for the first time in Eucalyptus species by these authors. According to the data provided, the predominant phenolic compounds in E. grandis and E. urograndis bark were epicatechin and quercetin-glucuronide, while those in E. maidenii bark were catechin, chlorogenic acid, and methyl-ellagic acid-pentose [15].

The by-products generated from the Eucalyptus wood industry were also studied to identify compounds with antioxidant potential. For instance, Celeiro et al. [40] analyzed three by-products from Eucalyptus greenboard manufacture, namely, the water derived from the washing of the wood chips, the condensates, and the concentrate of Eucalyptus. Using GC/MS and LC-MS/MS, the authors were able to identify up to 48 and 30 different compounds in the water from the washing of the wood chips and condensates, respectively, while the organic extracts derived from the concentrate of Eucalyptus presented up to 72 compounds. Chromatographic analyses highlighted the presence of monoterpenes, sesquiterpenes, polyphenols, and precursors of fragrance synthesis, as well as other biomolecules with antioxidant activity.

Using pyrolysis and gas chromatography coupled to mass spectrometry (Py-GC/MS) analysis, Gullón et al. [41] identified 21 compounds ( $\beta$-eudesmol, $\gamma$-eudesmol, and globulol, among others) from Eucalyptus leaf extract. The authors also conducted a Fourier-transform infrared spectroscopy (FTIR) analysis, revealing specific bands that can be attributed to different phenolic compounds such as flavonoids and polyphenols. More recently, related authors carried out a tentative identification of phenolic compounds in different extracts of E. globulus leaves using liquid chromatography coupled to trapped ion mobility spectrometry and TOF high-resolution mass spectrometry (UHPLC-TOF MS). The results revealed the possible presence of different bioactive molecules such as sideroxylonal A or $\mathrm{B}$, quercetin 3-O- $\beta$-D-glucuronide, and ellagic acid- or methylellagic acid-pentoside, among others ( $m / z$ 499.161, 477.067, 300.999, and 447.057, respectively) [42]. Table 1 summarizes some of the most commonly used methods to identify and quantify phenolics from Eucalyptus extracts.

Table 1. Phenolic compound characterization using analytical techniques reported for Eucalyptus extracts.

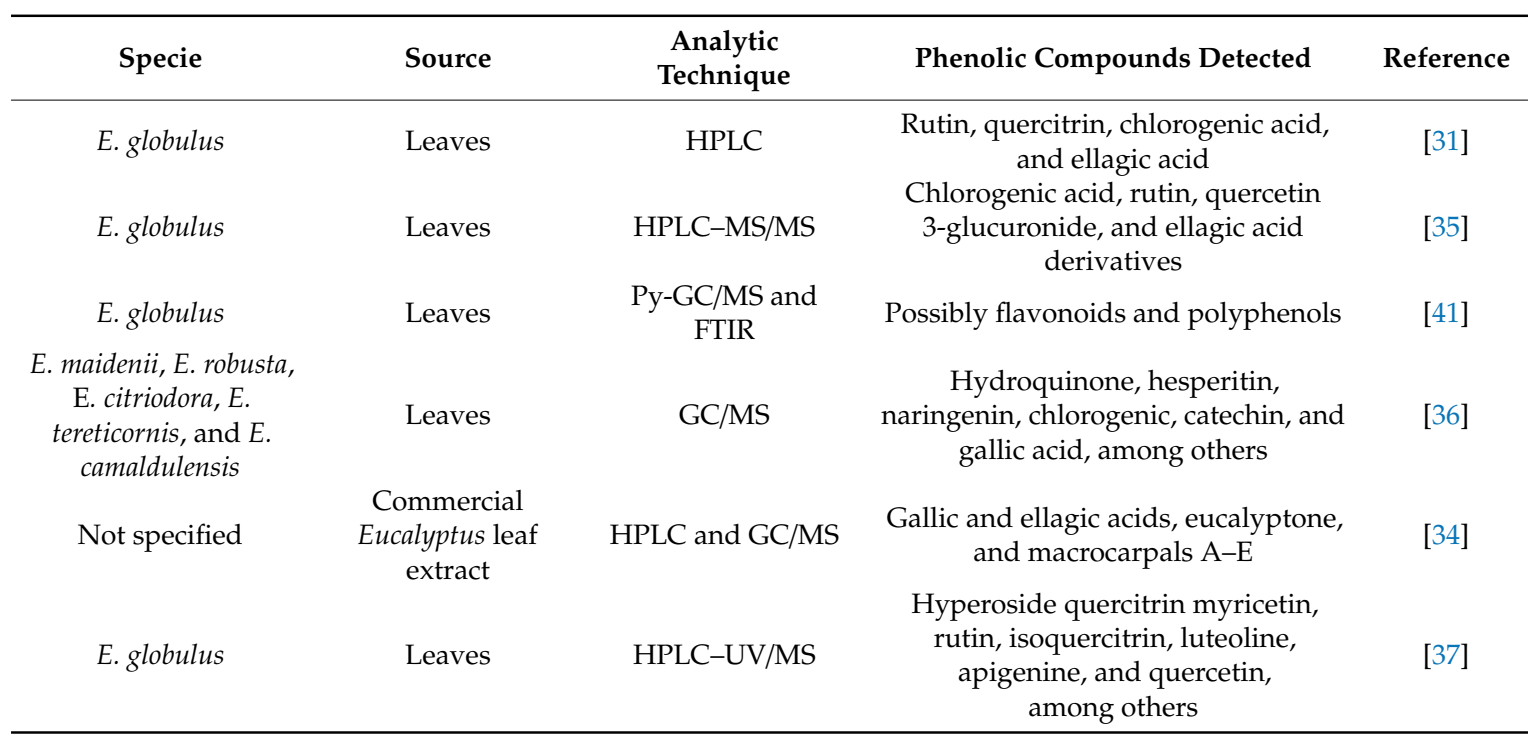


Table 1. Cont.

\begin{tabular}{|c|c|c|c|c|}
\hline Specie & Source & $\begin{array}{c}\text { Analytic } \\
\text { Technique }\end{array}$ & Phenolic Compounds Detected & Reference \\
\hline E. globulus & Leaves & UHPLC-TOF-MS & $\begin{array}{c}\text { Sideroxylonal A or B, quercetin } \\
\text { 3-O- } \beta \text {-D-glucuronide, and ellagic acid- } \\
\text { and methylellagic acid-pentoside, } \\
\text { among others }\end{array}$ & [42] \\
\hline E.camaldulensis & $\begin{array}{l}\text { Leaves, buds, } \\
\text { empty capsules, } \\
\text { and seeds }\end{array}$ & GC/MS & $\begin{array}{l}\text { Gallic acid, catechin, tricetin, } \\
\text { hydroquinone, pyrogallol, hesperitin, } \\
\text { and chlorogenic acid, among others }\end{array}$ & [38] \\
\hline E. globulus & Bark & $\begin{array}{l}\text { MALDI-TOF and } \\
\text { RP-HPLC-ESI-TOF }\end{array}$ & $\begin{array}{l}\text { Polygalloylglucoses mixtures } \\
\text { (gallotannins), catechin, epicatechin, } \\
\text { and ellagic acid, among others }\end{array}$ & [39] \\
\hline $\begin{array}{l}\text { E. grandis, E. maidenii } \\
\text { and E. urograndis }(E \text {. } \\
\text { grandis } \times \text { E. urophylla) }\end{array}$ & Bark & $\begin{array}{l}\text { HPLC-UV, } \\
\text { HPLC-MS/MS, } \\
\text { and MS }\end{array}$ & $\begin{array}{c}\text { Ellagic acid-rhamnoside, } \\
\text { dihydroxy-isopropylchromone-hexoside, } \\
\text { dihydroxy-(methylpropyl) } \\
\text { isopropylchromone-hexoside, } \\
\text { epicatechin, quercetin-glucuronide, } \\
\text { catechin, and chlorogenic acid, among } \\
\text { others }\end{array}$ & 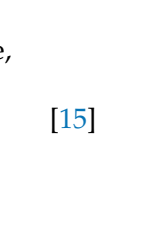 \\
\hline $\begin{array}{l}\text { By-products from the } \\
\text { Eucalyptus wood } \\
\text { industry }\end{array}$ & $\begin{array}{l}\text { Screw water, } \\
\text { condensates, } \\
\text { and concentrate }\end{array}$ & $\begin{array}{l}\text { GC/MS and } \\
\text { LC-MS/MS }\end{array}$ & $\begin{array}{c}\text { Gallic acid, protocatechuic acid, } \\
\text { chlorogenic acid, } \\
\text { 3,4-dihydroxybenzaldehyde, } \\
\text { 4-hydroxybenzaldehyde, geranyl } \\
\text { acetate, geranyl butyrate, } \\
\text { trans-geraniol, sesquiterpenes } \\
\text { (alloaromadendrene, ledene, } \\
\alpha \text {-Selinene, } \beta \text {-cadinene) }\end{array}$ & [40] \\
\hline E. globulus & $\begin{array}{l}\text { Wood industrial } \\
\text { wastes }\end{array}$ & RP-HPLC-ESI-TOF & $\begin{array}{c}\text { Ellagic acid, myricetin } \\
\text { 3-O-rhamnoside, and quercetin } \\
\text { 3-glucoside }\end{array}$ & [43] \\
\hline E. globulus & Leaves & $\begin{array}{l}\text { RP-HPLC and }{ }^{13} \mathrm{C}- \\
\text { and }{ }^{1} \mathrm{H}-\mathrm{NMR}\end{array}$ & $\begin{array}{l}\text { Cypellocarpin A, eucaglobulin, } \\
\text { cuniloside, and }(1 S, 2 S, \\
4 R) \text {-trans-2-hydroxy-1,8-cineole } \\
\beta \text {-D-glucopyranoside }\end{array}$ & [16] \\
\hline
\end{tabular}

HPLC: high-performance liquid chromatography; GC/MS: gas chromatography-mass spectrometry; MALDI-TOF: matrix-assisted laser desorption ionization time-of-flight; RP-HPLC-ESI-TOF: reverse-phase high-performance liquid chromatography electrospray ionization time-of-flight; Py-GC/MS: pyrolysis and gas chromatography coupled with mass spectrometry; UHPLC-TOF-MS: ultra-high-performance liquid chromatography coupled with trapped ion mobility spectrometry and TOF high-resolution mass spectrometry; FTIR: Fourier-transform infrared spectroscopy; NMR: nuclear magnetic resonance.

\section{Extraction Procedures of Polyphenols from Eucalyptus Species: from Conventional to Innovative Technologies}

The efficient recovery of phytochemicals from natural sources is mainly influenced by the method and the conditions used for extraction [27,44-48]. This stage must assure a high extraction performance and preserve the quality of the extracted compounds, in addition to meeting other requirements such as versatility, cost-effectiveness, and ease of operation [49] The most commonly applied method for the recovery and isolation of natural bioactive substances such as polyphenols is inarguably conventional solvent extraction [41,42]. Nevertheless, these processes are relatively inefficient due to them requiring large amounts of hazardous organic solvents, long periods of time, and high extraction temperatures, not to mention the need to remove the solvent to avoid contamination of the extracted compounds [50]. These inconveniences have motivated researchers to look for other more economically feasible and greener technologies for the obtaining of phenolics from several plant matrices [50]. Among these modern technologies, ultrasound-assisted extraction (UAE), microwave-assisted extraction (MAE), supercritical fluid extraction (SFE), and subcritical water extraction (SWE) have been applied to enhance the extraction efficiency and reduce the environmental impact of the conventional processes [2,33,42]. Some studies reported in the literature related to the extraction of phenolics from different species of Eucalyptus are presented in Table 2 and discussed in the sections below. 
Table 2. Extraction technologies for obtaining phenolic compounds from Eucalyptus biomass.

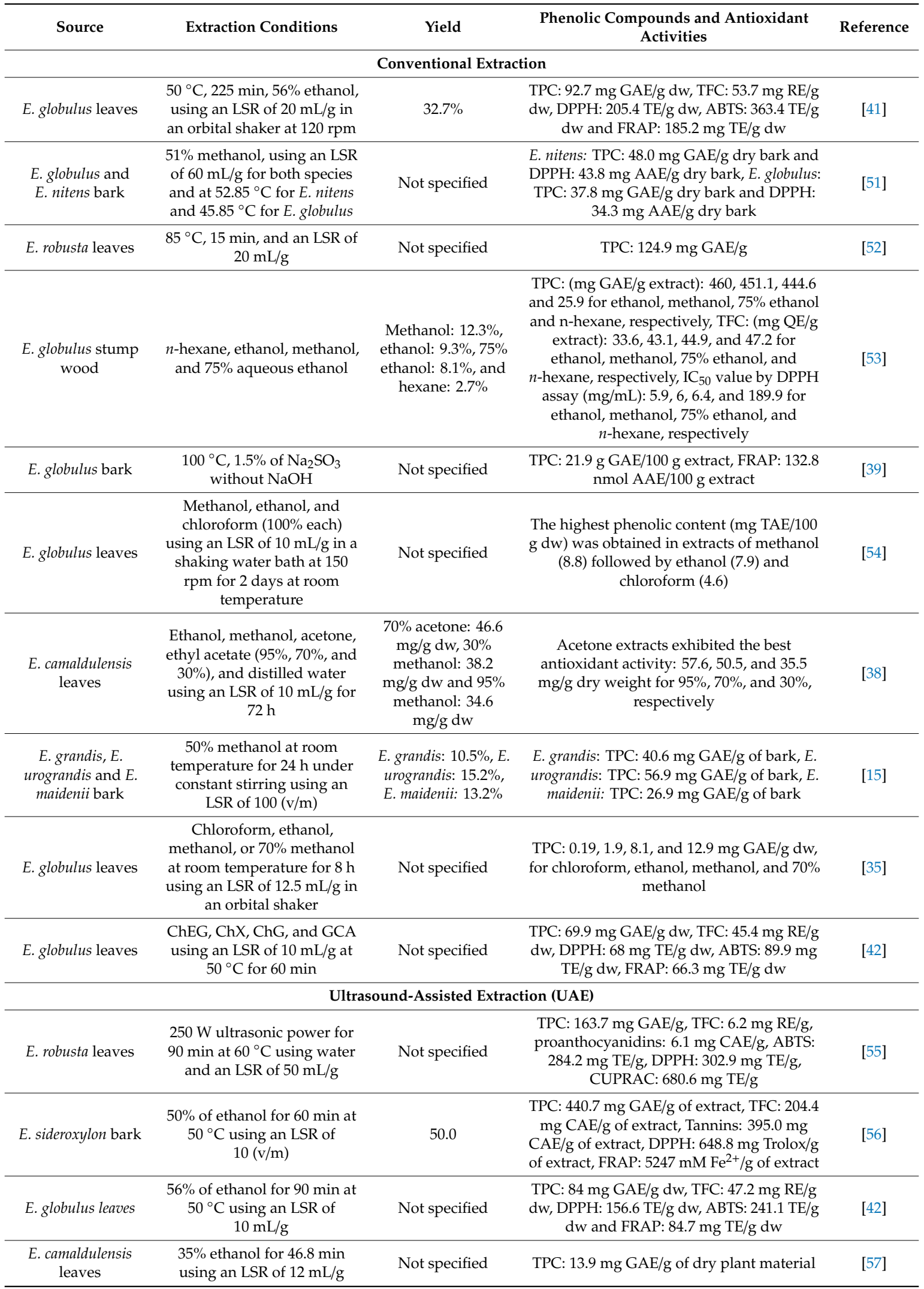


Table 2. Cont.

\begin{tabular}{|c|c|c|c|c|}
\hline Source & Extraction Conditions & Yield & $\begin{array}{l}\text { Phenolic Compounds and Antioxidant } \\
\text { Activities }\end{array}$ & Reference \\
\hline \multicolumn{5}{|c|}{ Microwave-Assisted Extraction (MAE) } \\
\hline E. robusta leaf & $\begin{array}{c}3 \mathrm{~min}, 600 \mathrm{~W} \text { power, and an } \\
\text { LSR of } 50 \mathrm{~mL} / \mathrm{g} \text { using water } \\
\text { as a solvent }\end{array}$ & Not specified & $\begin{array}{c}\text { TPC: } 58.4 \text { mg GAE/, TFC: } 19.2 \mathrm{mg} \mathrm{RE} / \mathrm{g} \text {, } \\
\text { proanthocyanidins: } 6.2 \mathrm{mg} \text { CAE/g, ABTS: } \\
74.9 \text { mg TE/g, DPPH: } 67.9 \mathrm{mg} \text { TE/g } \\
\text { CUPRAC: } 143.7 \mathrm{mg} \text { TE/g }\end{array}$ & [33] \\
\hline E. globulus leaves & $\begin{array}{l}56 \% \text { ethanol for } 7 \mathrm{~min} \text { using } \\
\text { an LSR of } 10 \mathrm{~mL} / \mathrm{g}\end{array}$ & Not specified & $\begin{array}{l}\text { TPC: } 79.4 \mathrm{mg} \text { GAE/g dw, TFC: } 39.4 \mathrm{mg} \mathrm{RE} / \mathrm{g} \\
\text { dw, DPPH: } 141.2 \mathrm{TE} / \mathrm{g} \mathrm{dw}, \mathrm{ABTS}: 187.4 \mathrm{TE} / \mathrm{g} \\
\text { dw and FRAP: } 105.8 \mathrm{mg} \text { TE/g dw }\end{array}$ & [42] \\
\hline $\begin{array}{l}\text { E. globulus wood } \\
\text { industrial wastes }\end{array}$ & $\begin{array}{c}\text { Ethanol for } 10 \mathrm{~min} \text { at } 65^{\circ} \mathrm{C} \\
\text { using an LSR of } 8.8 \mathrm{~mL} / \mathrm{g}\end{array}$ & $2.3 \%$ & $\begin{array}{c}\text { TPC: } 65.1 \text { g GAE/100 g extract, FRAP: } 5458 \\
\text { nmol AAE/mg extract }\end{array}$ & [58] \\
\hline $\begin{array}{l}\text { E. camaldulensis } \\
\text { Dehn leaves }\end{array}$ & $\begin{array}{l}50 \% \text { ethanol, } 600 \mathrm{~W} \text { power } \\
\text { for } 5 \mathrm{~min} \text { using an LSR of } \\
20 \mathrm{~mL} / \mathrm{g}\end{array}$ & Not specified & $\begin{array}{c}\text { TPC: } 76.6 \mathrm{mg} \text { GAE/g sample, TFC: } 5.8 \mathrm{mg} \\
\text { QE/g sample }\end{array}$ & [59] \\
\hline \multicolumn{5}{|c|}{ Supercritical Fluid Extraction (SFE) } \\
\hline $\begin{array}{l}\text { E. globulus Labill } \\
\text { bark }\end{array}$ & $\begin{array}{c}70{ }^{\circ} \mathrm{C}, 20 \% \text { ethanol as } \\
\text { cosolvent, } \mathrm{CO}_{2} \text { flow rate of } \\
10 \mathrm{~g} / \mathrm{min} \text { at } 300 \mathrm{bar}\end{array}$ & $0.5 \%$ & $\begin{array}{c}\text { TPC: } 57.2 \mathrm{mg} \mathrm{GAE} / \mathrm{g} \text { of extract, PC-HPLC: } \\
119.5 \mathrm{mg} / \mathrm{g} \text { of extract, and DPPH: } 49.7 \mathrm{mg} \\
\text { AAE/g of extract }\end{array}$ & {$[60]$} \\
\hline $\begin{array}{l}\text { E. camaldulensus } \\
\text { and E. cinerea } \\
\text { leaves }\end{array}$ & $\begin{array}{l}\text { SFE: } 40{ }^{\circ} \mathrm{C} \text {, for } 30 \mathrm{~min} \text { and } \\
90 \text { bar } \\
\text { Hydrodistillation (HD): } \\
100{ }^{\circ} \mathrm{C} \text { for } 3 \mathrm{~h}\end{array}$ & $\begin{array}{c}\text { E. camaldulensus: } \\
8.8 \mathrm{~g} / \mathrm{kg} \text { for SFE } \\
\text { and } 6.2 \mathrm{~g} / \mathrm{kg} \text { for } \\
\mathrm{HD}, \text { E. cinerea: } 27.5 \\
\mathrm{~g} / \mathrm{kg} \text { for SFE and } \\
23 \mathrm{~g} / \mathrm{kg} \text { for HD }\end{array}$ & $\begin{array}{l}\text { The extracts obtained by SFE exhibited a } \\
\text { powerful antioxidant activity compared to } \\
\text { those obtained by HD }\end{array}$ & [61] \\
\hline \multicolumn{5}{|c|}{ Subcritical Water Extraction (SWE) } \\
\hline E. grandis leaves & $\begin{array}{c}\text { SWE: } 160{ }^{\circ} \mathrm{C} \text { at } 3 \mathrm{MPa}, \mathrm{SE}: 7 \\
\text { days with constant stirring } \\
\text { using methanol as solvent }\end{array}$ & $\begin{array}{l}\text { SWE: } 290 \mathrm{mg} \text {, SE: } \\
312 \mathrm{mg}\end{array}$ & AA for SWE of $56.7 \%$ and for SE of $40.2 \%$ & {$[62]$} \\
\hline
\end{tabular}

Ch: choline chloride; EG: ethylene glycol; X: xylitol; CA: citric acid; LSR: liquid-to-solid ratio; TAE: tannic acid equivalent; CAE: catechin equivalents; GAE: gallic acid equivalents; RE: rutin equivalents; EY: extraction yield; TPC: total phenolic content; TFC: total flavonoid content; DPPH: $\alpha, \alpha$-diphenyl- $\beta$-picrylhydrazyl radical scavenging; ABTS: 2,2'-azino-bis-3-ethylbenzothiazoline-6-sulfonic acid; FRAP: ferric reducing antioxidant power; CUPRAC: cupric reducing antioxidant capacity; AAE: ascorbic acid equivalent; QE: quercetin equivalent; PC-HPLC: phenolic compounds quantified by HPLC; SE: solvent extraction; HD: hydrodistillation; SFE: supercritical fluid extraction; SWE: subcritical water extraction; AA: antioxidant activity; DW: dry weight.

\subsection{Conventional Technologies}

Conventional extraction methods such as Soxhlet, maceration, or hydrodistillation are widely used for the isolation of polyphenols. Several types of solvents such as ethanol, methanol, acetone, diethyl ether, and ethyl acetate in combination with water have been employed for the recovery of these compounds from Eucalyptus biomass. It is important to mention that conventional extraction is influenced by different factors (i.e., extraction time, temperature, and concentration of solvent) that must be carefully optimized to achieve high recovery of the target compounds. In this context, Gullón et al. [41] examined the effects of the operating conditions (temperature: $25-50{ }^{\circ} \mathrm{C}$, time: $30-300 \mathrm{~min}$, and percentage of ethanol: $20-80 \%$ ) on the extraction of compounds with antioxidant capacity from E. globulus leaves through response surface methodology (RSM). The results provided by the authors indicated that ethanol percentage had the greatest impact on all the dependent variables analyzed (extraction yield (EY), total phenolic content (TPC), total flavonoid content (TFC), and antioxidant activity determined by DPPH, ABTS, and FRAP). Optimal conditions for extraction were $50{ }^{\circ} \mathrm{C}, 225 \mathrm{~min}$, and $56 \%$ ethanol. Under these conditions, an extraction yield of $32.7 \%$, TPC of $92.7 \mathrm{mg} \mathrm{GAE} / \mathrm{g}$ dried leaf, TFC of $53.7 \mathrm{mg} \mathrm{RE} / \mathrm{g}$ dried leaf, and a high antioxidant activity (DPPH, ABTS, and FRAP of $205.4 \mathrm{mg}, 363.4$, and $185.2 \mathrm{mg}$ TE/g dried leaf, respectively), were achieved [41].

The influence of the type of solvent on the extraction efficiency of phenolic compounds from E. globulus biomass was evaluated by several authors. Luis et al. [53] found that of the four solvents tested in stump wood of E. globulus (n-hexane, ethanol, methanol, and $75 \%$ aqueous ethanol), methanol led to the highest extraction yield (12.3\%). Regarding the content of phenolic compounds, the three 
polar solvents yielded similar values; however, the highest flavonoid content was obtained for $n$-hexane extracts. All the extracts, except for those of $n$-hexane, exhibited strong antioxidant activity. In another study, Santos-Ferreira et al. [35] evaluated four solvents, namely, chloroform, ethanol, methanol, and $70 \%$ methanol, for the recovery of phenolic compounds from E. globulus leaves, and they found that methanol and aqueous methanol were the solvents that led to a higher recovery of phenolics. More recently, Nasr et al. [38] reported that 70\% acetone is the most suitable solvent for the extraction of phenolic compounds from E. camaldulensis leaves, while the most outstanding antioxidant activity was found in the extracts obtained with $95 \%$ acetone.

As previously mentioned, although these solvents are used in industrial processes for the extraction of phenolic compounds from different natural sources, their use has several disadvantages since they cause health risks and environmental problems. To overcome these drawbacks, deep eutectic solvents (DES) were recently proposed as sustainable and safe alternatives to replace common organic solvents in the extraction of phenolic compounds [63]. These solvents are characterized by their excellent biocompatibility, low toxicity, availability, and low cost [19]. These solvents were used for the extraction of specific compounds from some natural sources, such as rutin from the flower buds of Sophora japonica and tartary buckwheat hull [64,65]. However, DES applied to Eucalyptus biomass was only reported by Gullón et al. [42] who investigated the ability of three DESs formulated with choline chloride (Ch) and ethylene glycol (EG), xylitol (X), and glucose (G) and another mixture containing glucose and citric acid (CA) to extract natural antioxidants from Eucalyptus leaves. The authors found that only the blends synthesized with ChEG led to similar TPC and TFC values to those obtained using 56\% ethanol (considered as a benchmark); however, the antioxidant capacity of this extract was greatly lower (between 1.1- and 2.6-fold lower compared to the ethanolic extracts).

\subsection{Innovative Extraction Technologies}

In order to improve the extraction performance, reduce the operation time and the amount of solvent used, and to meet the growing demand for natural bioactive compounds, some modern techniques are preferred.

\subsubsection{Ultrasound-Assisted Extraction (UAE)}

Ultrasound-assisted extraction (UAE) has been identified as an effective and eco-friendly alternative to conventional extraction methods. This technique stands out for its simplicity, versatility, and cost-effectiveness due to the low volume of solvent required. It operates at mild temperatures, with less time and energy consumption, making it one of the most suitable extraction systems for large-scale operations $[55,66,67]$. For extraction purposes based on ultrasound, high-frequency waves ( $>2 \mathrm{MHz}$ ) are applied which favor the formation of cavitation bubbles. This phenomenon is responsible for the disruption of the cellular structure of the sample, facilitating the contact between solvent and cellular material, which consequently improves the mass transfer and increases the extraction efficiency $[68,69]$. In recent years, some authors applied ultrasound to extract phenolics from Eucalyptus biomass. Many of these studies focused on the optimization of several operational variables that affect the extraction efficiency of UAE, such as temperature, ultrasonication time, power, and frequency [42,55]. In this line, Bhuyan et al. [55] designed an optimization process for the recovery of phenolic compounds from Eucalyptus robusta leaves through RSM. The working parameters evaluated were temperature (30, $\left.45,60^{\circ} \mathrm{C}\right)$, time $(30,60,90 \mathrm{~min})$, and power $(150,200,250 \mathrm{~W})$, using water as a solvent. The statistical results indicated that temperature was the variable with the greatest impact on the yield of TPC, followed by time and power. The proanthocyanidin content, as well as the antioxidant activity determined by ABTS, DPPH, and CUPRAC, was also mainly influenced by the temperature. On the other hand, the recovery of flavonoids was only affected by sonication time. Under optimized extraction conditions $\left(250 \mathrm{~W}\right.$ ultrasonic power for $90 \mathrm{~min}$ at $60{ }^{\circ} \mathrm{C}$ with water using a liquid-to-solid ratio (LSR) of $50 \mathrm{~mL} / \mathrm{g}$ ), UAE led to yield of TPC of $163.7 \mathrm{mg} \mathrm{GAE} / \mathrm{g}$, TFC of $6.2 \mathrm{mg} \mathrm{RE} / \mathrm{g}$, and proanthocyanidin of $6.1 \mathrm{mg} \mathrm{CAE} / \mathrm{g}$, with high antioxidant capacity $(284.2,302.9$, and $680.6 \mathrm{mg}$ TE/g for ABTS, DPPH and 
CUPRAC, respectively). In a previous study, Wong Paz et al. [57] also evaluated the effects of various operating parameters (\% ethanol, time, and LSR) on the extraction of polyphenols from E. camaldulensis leaves. The authors indicated that the LSR had a strong positive impact on the TPC yield.

Recently, Gullón et al. [42] compared UAE $\left(50{ }^{\circ} \mathrm{C}\right.$ for $\left.90 \mathrm{~min}\right)$ with conventional extraction $\left(50{ }^{\circ} \mathrm{C}\right.$ for $225 \mathrm{~min}$ ) using $56 \%$ ethanol and an LSR of $10 \mathrm{~mL} / \mathrm{g}$ for the isolation of antioxidants from Eucalyptus leaves. The results indicated that UAE led to similar values of TPC and TFC, but with lower energy consumption ( 0.082 vs. $0.177 \mathrm{kWh} / \mathrm{g}$ GAE), which confirms the suitability of UAE as a technology for the extraction of phytochemicals from natural sources.

\subsubsection{Microwave-Assisted Extraction (MAE)}

Microwave-assisted extraction (MAE) is another promising alternative to recover phenolic compounds from Eucalyptus biomass due to its lower processing cost (requires less solvent, energy, and time), higher extraction yields, and better quality of the extracted compounds [19,70]. Microwave extraction is based on the application of electromagnetic radiation that causes an increase in temperature and pressure within the plant matrix, resulting in cell-structure disruption, which in turn facilitates the release of phytochemicals to the extractant $[49,50]$. As in UAE, various operational parameters including microwave power, LSR, temperature, and time are involved in the MAE process and must be carefully controlled to ensure high extraction performance and selectivity of recovered compounds. Some researchers also reported the optimization of extracted polyphenols from Eucalyptus. Bhuyan et al. [33] conducted a study to elucidate the optimal operating conditions of the microwave system to obtain maximum levels of phytochemicals, namely, phenolics, flavonoids, and proanthocyanidins with high antioxidant activity from $E$. robusta leaf. The independent variables studied were irradiation time (1-3 $\mathrm{min})$, power $(480-720 \mathrm{~W})$, and LSR $(12.5-50 \mathrm{~mL} / \mathrm{g})$ using water as a solvent. The authors noted that LSR had the greatest impact on the performance of TPC and proanthocyanidins, as well as on the antioxidant capacity determined by the ABTS assay. Under optimized extraction conditions ( $3 \mathrm{~min}, 600 \mathrm{~W}$ power, and an LSR of $50 \mathrm{~mL} / \mathrm{g}$ ), a TPC of $58.4 \mathrm{mg} \mathrm{GAE} / \mathrm{g}$ and TFC of $19.2 \mathrm{mg}$ RE/g were achieved. Furthermore, these conditions also led to an extract enriched in proanthocyanidins $(6.2 \mathrm{mg}$ CAE/g) and antioxidant activity of $74.9 \mathrm{mg} \mathrm{TE} / \mathrm{g}$ for ABTS, $67.9 \mathrm{mg} \mathrm{TE} / \mathrm{g}$ for DPPH, and $143.7 \mathrm{mg}$ TE/g for CUPRAC, which represents between $62 \%$ and $67 \%$ of the maximum predicted by the model for these responses.

Fernández-Agulló et al. [58] compared MAE $\left(65^{\circ} \mathrm{C}, 10 \mathrm{~min}\right.$, LSR of $\left.8.8 \mathrm{~mL} / \mathrm{g}\right)$ with conventional extraction $\left(50^{\circ} \mathrm{C}, 90 \mathrm{~min}\right.$, LSR of $10 \mathrm{~mL} / \mathrm{g}$ ) for the recovery of bioactive compounds from Eucalyptus wood industrial wastes. According to the authors, maceration resulted in an extract with the best characteristics in terms of phenolic content and antioxidant potential; however, MAE was more efficient since it allowed significantly reducing the extraction time and the LSR. In a previous study, Gharekhani et al. [59] also compared MAE with UAE and traditional extraction. The results indicated that the MAE for 5 min extracted the same content of phenolic and flavonoid compounds as 60 min of UAE or conventional extraction at room temperature for $24 \mathrm{~h}$. Recently, Gullón et al. [42] explored the use of MAE for the extraction of health-promoting phenolics from Eucalyptus leaves. The authors demonstrated that the use of microwaves allowed obtaining an extract with similar content of phenolic compounds and flavonoids, as well as antioxidant activity, but with an almost 14-fold lower energy consumption compared to conventional extraction.

\subsubsection{Supercritical Fluid Extraction (SFE)}

Supercritical Fluid Extraction (SFE) has been established as an efficient green extraction technology used extensively to selectively isolate heat-sensitive high-value compounds from several natural sources. One important property of supercritical fluids is the possibility of modifying their solubility by changing their pressure and/or temperature; thus, these fluids can extract a wide spectrum of molecules of different polarities $[48,71]$. Of all possible supercritical fluids, carbon dioxide $\left(\mathrm{CO}_{2}\right)$ is the most widely used because of its many advantages: nonflammable, noncorrosive, innocuous to 
human health, environmentally friendly, economical, abundant, and reusable. Furthermore, its critical parameters of low value (temperature of $31.1^{\circ} \mathrm{C}$ and pressure of $73.8 \mathrm{bar}$ ) make it suitable for the extraction of thermolabile molecules $[50,72]$. Another important advantage of supercritical $\mathrm{CO}_{2}$ is that provides high-quality extracts free of organic solvents without the need for additional purification sequences [73]. However, due to the lack of polarity of $\mathrm{CO}_{2}$, it is ineffective to extract polar bioactive compounds (e.g., phenolics); hence, the addition of cosolvents (modifiers) such as ethanol or methanol is necessary to improve the extraction of these target compounds [74,75]. In general, the amount of cosolvent to be added varies from $1 \%$ to $15 \%$ [76].

Santos et al. [60] studied the influence of temperature, ethanol content, and $\mathrm{CO}_{2}$ flow rate on EY, TPC, the total amount of phenolic compounds quantified by HPLC, and antioxidant activity during SFE of biocompounds from E. globulus bark. The results indicated that the ethanol content had a positive impact on the four variables analyzed, whereas the temperature did not influence the phenolic profile, and the $\mathrm{CO}_{2}$ flow rate only affected the TPC.

In another study, Herzi et al. [61] compared SFE (90 bar, $40{ }^{\circ} \mathrm{C}, 30 \mathrm{~min}$ ) with hydrodistillation $\left(100{ }^{\circ} \mathrm{C}, 3 \mathrm{~h}\right)$ for the extraction of essential oil from two abundant species of the Tunisian forest, namely, E. camaldulensis and E. cinerea. The superiority of each technique was evaluated on the basis of performance, volatile chemical profile, phenolics, and antioxidant capacity. The results showed that SFE led to a higher extraction yield ( $27.5 \mathrm{vs.} 23 \mathrm{~g} / \mathrm{kg}$ for E. cinerea and $8.8 \mathrm{vs.} 6.2 \mathrm{~g} / \mathrm{kg}$ for E. camaldulensis) and extracts with stronger antioxidant activity (IC 50 ABTS of 65 vs. $399 \mathrm{mg} / \mathrm{L}$ for E. cinerea and $128 \mathrm{vs.}$ $183 \mathrm{mg} / \mathrm{L}$ for E. camaldulensis).

\subsubsection{Subcritical Water Extraction (SWE)}

Subcritical water extraction (SWE) employs water at temperatures between $100{ }^{\circ} \mathrm{C}$ (boiling temperature) and $374{ }^{\circ} \mathrm{C}$ (critical temperature) at a pressure high enough to keep the water in a liquid state [77]. Under these conditions, the polarity of the water is lower; thus, the solubility of many organic compounds is improved compared to normal water [62] This process can be considered a green option to conventional extraction that uses organic solvents. In this context, Kulkarni et al. [62] evaluated the effectiveness of SWE for the recovery of antioxidants from E. grandis leaves. The authors compared SWE with solvent extraction in terms of extract performance and antioxidant potential. SWE led to similar extraction yields to conventional extraction (290 mg and $312 \mathrm{mg}$, respectively); however, SWE extracts presented 1.4-fold higher antioxidant capacity (measured by the ability of the samples to scavenge peroxynitrite free radicals in vitro) than the conventional extract (56.7\% and $40.2 \%$, respectively).

\section{Biological Activities of Extracts Obtained from Eucalyptus Biomass}

As mentioned previously, Eucalyptus biomass contains diverse phenolic compounds to which a plethora of therapeutic properties such as antibacterial, antifungal, antioxidant, neuroprotective, and anticancer activities, inter alia, are attributed.

\subsection{Antioxidant Activity}

The antioxidant activity of Eucalyptus biomass extracts is extensively reported in the literature. For example, Ashraf et al. [78] evaluated the antioxidant activity of different extracts (methanol, chloroform, and hexane) from E. camaldulensis leaves. Methanol extracts proved to have higher antioxidant potential than those obtained with the other solvents with $\mathrm{IC}_{50}$ values determined by free radical (DPPH) scavenging of $89.11 \mu \mathrm{g} / \mathrm{mL}$ (methanol), $154.8 \mu \mathrm{g} / \mathrm{mL}$ (chloroform), and $532.9 \mu \mathrm{g} / \mathrm{mL}$ (hexane). The authors indicated that the compounds responsible for this antioxidant activity were mainly phenolic acids (gallic acid, p-hydroxybenzoic acid, syringic acid, and vanillic acid) and flavonoids (catechin and quercetin). González et al. [51] studied the antioxidant capacity of ethanolic extracts obtained from the bark of two Eucalyptus species, namely, E. globulus and E. nitens. The results 
revealed that $E$. nitens bark extracts exhibited the highest antioxidant activity with DPPH values of 43.8 vs. $34.3 \mathrm{mg}$ AAE/g dry bark.

In another study, Vuong et al. [52] investigated the antioxidant activity of an aqueous extract from E. robusta leaves through several in vitro methods, namely, ABTS, DPPH, hydrogen peroxide $\left(\mathrm{H}_{2} \mathrm{O}_{2}\right)$, CUPRAC (cupric ion reducing antioxidant capacity), and FRAP (ferric reducing antioxidant power), and the results were compared with those obtained for $\alpha$-tocopherol and ascorbic acid (considered as reference antioxidants). According to the authors, the extract presented an antioxidant capacity similar to that of ascorbic acid and significantly higher than that of $\alpha$-tocopherol. They also highlighted that the potent antioxidant activity of these extracts could be enhanced with an additional purification step. The potential antioxidant effect of other polyphenolic extracts obtained from different Eucalyptus biomass is compiled in Table 3.

Table 3. Biological activities of the extracts obtained from Eucalyptus biomass.

\begin{tabular}{|c|c|c|}
\hline Source/Type of Extract & Outcomes & Reference \\
\hline $\begin{array}{c}\text { Leaves of E. camaldulensis Dehn. extracted } \\
\text { with three different solvents (methanol, } \\
\text { chloroform, and hexane) }\end{array}$ & $\begin{array}{c}\mathrm{IC}_{50}(\mu \mathrm{g} / \mathrm{mL}) \text { determined by DPPH: } 89.1 \mu \mathrm{g} / \mathrm{mL} \text { (methanol), } \\
154.8 \mu \mathrm{g} / \mathrm{mL} \text { (chloroform), } 532.9 \mu \mathrm{g} / \mathrm{mL} \text { (hexane) }\end{array}$ & {$[78]$} \\
\hline $\begin{array}{l}\text { Fruits of E. globulus extracted with } 70 \% \\
\text { acetone-water containing } 0.5 \% \text { acetic acid }\end{array}$ & $\begin{array}{l}\text { High reducing power and moderate inhibition of lipid } \\
\text { peroxidation of linoleic acid emulsion; reducing power: } \mathrm{IC}_{50} \\
\quad=39.5 \mu \mathrm{g} / \mathrm{mL} \text {, lipid peroxidation inhibition }=51.3 \%\end{array}$ & {$[4]$} \\
\hline $\begin{array}{l}\text { E. globulus leaves extracted with } \\
\qquad 70 \% \text { ethanol }\end{array}$ & $\begin{array}{c}\text { DPPH: } 15.3 \mu \mathrm{g} \text { QE/mg plant material, ABTS: } 9.0 \mu \mathrm{g} \text { TE } / \mathrm{mg} \\
\text { plant material, HAPX: } 61.2 \%\end{array}$ & {$[37]$} \\
\hline $\begin{array}{l}\text { Ethanolic extracts obtained from the bark of } \\
\text { E. globulus and E. nitens }\end{array}$ & $\begin{array}{c}\text { DPPH (mg AAE/g dry bark): } 43.1 \text { for E. nitens and } 35 \text { for } \\
\text { E. globulus }\end{array}$ & {$[51]$} \\
\hline $\begin{array}{l}\text { Stumps of E. globulus using } n \text {-hexane, } \\
\text { methanol, ethanol, and } 75 \% \text { ethanol }\end{array}$ & $\begin{array}{c}\mathrm{IC}_{50}(\mathrm{mg} / \mathrm{L}) \text { determined by DPPH: } n \text {-hexane } 170.3-369.3 \\
\mathrm{mg} / \mathrm{L} \text {, ethanol 5.9-11.3 mg/L, methanol 6-12.5 mg/L, and } 75 \% \\
\text { ethanol } 6.35-17.3 \mathrm{mg} / \mathrm{L}\end{array}$ & {$[53]$} \\
\hline Bark of E. sideroxylon & $\begin{array}{c}\text { DPPH: } 648.8 \mathrm{mg} \text { Trolox/g of extract, and FRAP: } 5247 \mathrm{mM} \\
\qquad \mathrm{Fe}^{2+} / \mathrm{g} \text { of extract }\end{array}$ & {$[56]$} \\
\hline $\begin{array}{c}\text { Methanolic extracts of E. grandis wood from } \\
\text { Portugal, Brazil, and South Africa }\end{array}$ & $\begin{array}{l}\mathrm{IC}_{50} \text { determined by DPPH: E. grandis Portugal: } 6.2 \mu \mathrm{g} / \mathrm{mL} \text {, } \\
\text { E. grandis Brazil: } 5.1 \mu \mathrm{g} / \mathrm{mL}, \text { E. grandis South Africa: } 6.1 \\
\mu \mathrm{g} / \mathrm{mL} \text {. ABTS: E. grandis Portugal: } 10.0 \mathrm{mg} \text { AAE } / \mathrm{g} \text { of dry } \\
\text { wood, E. grandis Brazil: } 23.4 \mathrm{mg} \text { AAE/g of dry wood, } \\
\text { E. grandis South Africa: } 13.9 \mathrm{mg} \text { AAE/g of dry wood }\end{array}$ & {$[80]$} \\
\hline \multicolumn{3}{|c|}{ Antimicrobial Activity } \\
\hline $\begin{array}{l}\text { Fruits of E. globulus extracted with } 70 \% \\
\text { acetone-water containing } 0.5 \% \text { acetic acid }\end{array}$ & $\begin{array}{c}\text { Growth inhibition of Bacillus subtilis (MIC of } 30 \mu \mathrm{g} / \mathrm{mL} \text { ) and } \\
\text { Staphylococcus aureus (MIC of } 80 \mu \mathrm{g} / \mathrm{mL}) \text {. No inhibition of } \\
\text { Klebsiella pneumoniae }\end{array}$ & {$[4]$} \\
\hline Ethanolic extract from E. globulus leaves & $\begin{array}{l}\text { MIC values (mg/mL): S. aureus (35), Listeria innocua (30), B. } \\
\text { cereus (40), Escherichia coli (40), Pseudomonas aeruginosa (45), } \\
\text { and Salmonella spp. }(45) \\
\text { MBC values }(\mathrm{mg} / \mathrm{mL}) \text { : S. aureus }(40), \text { L. innocua }(35), \text { B. cereus } \\
(45), \text { E. coli }(50), \text { P. aeruginosa }(50), \text { and Salmonella spp. }(50)\end{array}$ & {$[41]$} \\
\hline Ethanolic extract from E. globulus leaves & $\begin{array}{l}\text { MIC values }(\mu \mathrm{g} / \mathrm{mL}): \text { S. aureus 50, B. subtilis }>100, L . \\
\text { monocytogenes } 30, \text { E. coli }>100, \text { S. typhimurium }>100\end{array}$ & {$[37]$} \\
\hline
\end{tabular}


Table 3. Cont.

\begin{tabular}{|c|c|c|}
\hline Source/Type of Extract & Outcomes & Reference \\
\hline Extract from E. globulus leaves & $\begin{array}{l}\text { High acute toxicity with } \mathrm{LD}_{50}=38 \mu \mathrm{g} \text { against Leptinotarsa } \\
\text { decemlineata larvae }\end{array}$ & [2] \\
\hline $\begin{array}{l}\text { Extracts of E. globulus (stump wood, stump } \\
\text { bark, and industrial chips) }\end{array}$ & $\begin{array}{l}\text { The different extracts exhibited low MIC values } \\
(0.156-10 \mathrm{mg} / \mathrm{mL} \text { ) against several strains of } S \text {. aureus } \\
\text { (including MRSA strains) food-borne pathogens (B. cereus } \\
\text { and L. monocytogenes), Candida strains, and some } \\
\text { Gram-negative bacteria (E. coli, P. aeruginosa, K. pneumoniae) }\end{array}$ & [53] \\
\hline \multicolumn{3}{|c|}{ Other Activities } \\
\hline $\begin{array}{l}\text { Aqueous acetone leaf extract of } E \text {. } \\
\text { camaldulensis Dehnh }\end{array}$ & $\begin{array}{l}\text { Cytotoxic effect on tumor cell lines: breast adenocarcinoma, } \\
\text { human epithelial laryngeal carcinoma, hepatocellular } \\
\text { carcinoma, human cervix adenocarcinoma, colorectal } \\
\text { adenocarcinoma, and Caco-2 colon adenocarcinoma }\end{array}$ & [82] \\
\hline Aqueous extracts from E. globulus Labill. & $\begin{array}{l}\text { Antitumor activity on colorectal, pancreatic, } \\
\text { and non-small-cell lung cancer }\end{array}$ & [83] \\
\hline
\end{tabular}

Isolated compounds of E. globulus leaves: 2,

2, 8-trimethyl-6-formyl-chrom-3-ene Nephroprotective role against diabetes mellitus and kidney

7-O- $\beta$-D-glucopyranoside, quercetin

3-O- $\alpha-\mathrm{L}-4 \mathrm{C} 1$ arabinopyranoside-2"-gallate, stone disease cornusiin B, and eucalbanin B

\begin{tabular}{cc}
\hline E. globulus leaves & Neuroprotective activity \\
\hline E. globulus leaves & Antiobesity activity: 90\% inhibition of pancreatic lipase \\
activity & [79] \\
\hline E. grandis $\times$ E. urophylla bark & $\begin{array}{c}\text { Prevention of hyperglycemia through the inhibition of } \\
\alpha \text {-glucosidase and } \alpha \text {-amylase activities }\end{array}$ \\
\hline
\end{tabular}

QE: quercetin; TE: Trolox equivalent; HAPX: hemoglobin/ascorbate peroxidase activity inhibition assay; AAE: ascorbic acid equivalent; BHT: butylated hydroxytoluene; MIC: minimum inhibition concentration; MBC: minimum bactericidal concentration.

\subsection{Antimicrobial Activity}

In addition to the antioxidant properties associated with phenolic extracts derived from different biomass of the Myrtaceae family, several studies also reported their role as antimicrobial agents [14,37,41]. This is especially interesting because more and more microorganisms are becoming resistant to available antibiotics; thus, there is an urgent need to search for alternative biomolecules that can inhibit the broad spectrum of multidrug-resistant microorganisms [20,86]. Boulekbache-Makhlouf et al. [4] demonstrated the antimicrobial potential of crude extract from the fruit of E. globulus against three bacteria, namely, Staphylococcus aureus, Bacillus subtilis, and Klebsiella pneumoniae. The extract was effective against the two Gram-positive strains (S. aureus, B. subtilis) but had no inhibitory effect against K. pneumoniae (Gram-negative bacteria). Gullón et al. [41] also established that the ethanolic extract obtained from Eucalyptus leaf exhibited antibacterial activity against three Gram-positive (S. aureus, Listeria innocua, and B. cereus) and three Gram-negative bacteria (Escherichia coli, Pseudomonas aeruginosa, and Salmonella spp.). Although the authors did not attribute this activity to any specific compound, the evaluated extract contained several compounds, including $\beta$-eudesmol, $\gamma$-eudesmol, globulol, and $n$-hexadecanoic acid, with their combined action responsible for the antibacterial activity of the extract. In another interesting work, Gomes et al. [81] demonstrated that methanolic extracts of Eucalyptus leaves were effective against several S. aureus strains responsible for bovine mastitis. 
The authors related this positive effect to the combination of several phenolic compounds such as gallotannins, ellagic acid glycoside, and quercetin derivatives.

Some authors also confirmed the antifungal effect of phenolic components extracted from the bark of E. globulus and E. nitens [51]. These extracts displayed inhibition of the growth of the fungal species Tinea versicolor. Moreover, E. globulus extracts with a high concentration of volatiles (1,8-cineole, aromadendrene, $\alpha$-pinene, and globulol) exhibited insecticidal activity against Leptinotarsa decemlineata larvae; therefore, these products could be suitable for the formulation of products intended to slow the growth of larvae in gardens and fields [2]. Overall, the results of these investigations open new opportunities for innovative therapeutic approaches using plant phenolics to reduce the drug resistance of many disease-causing microorganisms. Other studies on the antimicrobial potential of different extracts from Eucalyptus biomass are present in Table 3.

\subsection{Other Activities}

Some studies carried out in the last decade reported that Eucalyptus extracts are promising anticancer agents against different types of tumor cells [52,87-89]. For instance, Vuong et al. [52] evaluated anticancer activity of an aqueous extract from $E$. robusta leaves on various human cancer cell lines, namely, HT29 (colon), U87, SJ-G2, SMA (glioblastoma), MCF-7 (breast), A2780 (ovarian), H460 (lung), A431 (skin), Du145(prostate), BE2-C (neuroblastoma), and MiaPaCa-2 (pancreas). The data indicated that this extract displayed antitumor activity against all cancer cell lines tested. Furthermore, the authors also highlighted that Eucalyptus extract exerted a more significant cytotoxic effect on pancreatic cancer tumor cells compared to gemcitabine, which is considered one of the most relevant anticancer drugs for this type of cancer. Interestingly, the results also revealed that the compounds present in the Eucalyptus extract had few negative effects on normal pancreatic ductal epithelial cells. In previous work, Singab et al. [82] also demonstrated that the phenolic constituents of an aqueous acetone extract from E. camaldulensis Dehnh had a cytotoxic effect on tumor cell lines, particularly on MCF-7 (breast adenocarcinoma) and HCT-116 (colorectal adenocarcinoma) cell lines, in a dose-dependent manner.

Aqueous extracts from E. globulus Labill. also presented antitumor activity on colorectal, pancreatic, and non-small-cell lung cancer (HCT-15, PANC-1, and NCI-H460, respectively) [83]. In the particular case of NCI-H460, E. globulus decoction extract resulted in a dose-dependent decrease in the number of cells, limiting the cell cycle in the G0/G1 phase, with a reduction in cell proliferation and a rise in the expression of p53, p21, and cyclin D1 proteins.

The neuroprotective potential of E. globulus extracts was tested in vitro by González-Burgos et al. [79] in human neuroblastoma SH-SY5Y cells. The authors noted that these extracts have the ability ameliorate $\mathrm{H}_{2} \mathrm{O}_{2}$-induced oxidative stress damage through several mechanisms: decreasing the production of ROS and lipid peroxidation and increasing the cell viability, GSH (glutathione) concentration, and antioxidant enzyme activity.

The antiobesity role of Eucalyptus extracts was demonstrated by Iyyappan et al. [54] who observed a $90 \%$ inhibition of pancreatic lipase activity due to the phenolic compounds present in the extract. In another study, phenolic extracts from E. grandis $\times E$. urophylla bark showed a potent inhibition of $\alpha$-amylase and $\alpha$-glucosidase activity associated with hyperglycemia.

\section{Conclusions}

On the basis of the information compiled in this review, we can conclude that the different parts of Eucalyptus biomass are excellent sources of value-added compounds with promising bioactivities. While it is true that, in the last few decades, the interest in the search for new compounds from natural sources with similar or enhanced properties as substitutes of the synthetic antioxidants or conventional antibiotics has increased, Eucalyptus species have been used in folk medicine to treat different ailments. Great efforts have been devoted to isolating and identifying the compounds present in the plants belonging to the Myrtaceae family, with phenols being mainly responsible for their beneficial properties. 
Moreover, the limitations of the conventional extraction technologies involve their operational time and temperature, harmful organic solvents, and degradation of the thermolabile compounds, which were overcome through the development and application of emerging technologies combined with greener smart solvents. These avant-garde techniques have allowed achieving high extraction yields with high antioxidant activities, while maintaining the properties of the obtained extracts. Until now, the in vitro biological activities of extracts from different Eucalyptus species were demonstrated, such as antioxidant, antimicrobial, anticarcinogenic, neuroprotective, and antihyperglycemic properties, among others. Therefore, the different parts of Eucalyptus species have great potential as natural sources to obtain active biologically compounds that respond to the increasing demand of consumers for natural products to treat some disorders and enhance their quality of life.

Author Contributions: Conceptualization, B.G.; writing-original draft preparation, P.G., G.A., and B.G.; writing-review and editing, P.G., G.A., B.G., P.E.S.M., M.P., and J.M.L. All authors read and agreed to the published version of the manuscript.

Funding: The authors thank GAIN (Axencia Galega de Innovación) for supporting this research (grant number IN607A2019/01).

Acknowledgments: B.G. acknowledges postdoctoral fellowship support from the Ministry of Economy and Competitiveness (MINECO, Spain) "Ramón y Cajal" program (Grant reference RYC2018-026177-I). G.A. thanks the University of Vigo for his contract supported by "Programa de retención de talento investigador da Universidade de Vigo para o 2018" budget application 0000 131H TAL 641. J.M.L. is member of the HealthyMeat network, funded by CYTED (ref. 119RT0568).

Conflicts of Interest: The authors declare no conflict of interest.

\section{References}

1. Granato, D.; Barba, F.J.; Bursać Kovačević, D.; Lorenzo, J.M.; Cruz, A.G.; Putnik, P. Functional foods: Product development, technological trends, efficacy testing, and safety. Annu. Rev. Food Sci. Technol. 2020, 11, 93-118. [CrossRef] [PubMed]

2. Topiar, M.; Sajfrtova, M.; Pavela, R.; Machalova, Z. Comparison of fractionation techniques of $\mathrm{CO}_{2}$ extracts from Eucalyptus globulus-Composition and insecticidal activity. J. Supercrit. Fluids 2015, 97, 202-210. [CrossRef]

3. Munekata, P.E.S.; Alcántara, C.; Collado, M.C.; Garcia-Perez, J.V.; Saraiva, J.A.; Lopes, R.P.; Barba, F.J.; do Prado Silva, L.; Sant'Ana, A.S.; Fierro, E.M.; et al. Ethnopharmacology, phytochemistry and biological activity of Erodium species: A review. Food Res. Int. 2019, 126, 108659. [CrossRef] [PubMed]

4. Boulekbache-Makhlouf, L.; Slimani, S.; Madani, K. Total phenolic content, antioxidant and antibacterial activities of fruits of Eucalyptus globulus cultivated in Algeria. Ind. Crops Prod. 2013, 41, 85-89. [CrossRef]

5. Lorenzo, J.M.; Mousavi-Khaneghah, A.; Gavahian, M.; Marszałek, K.; Es, I.; Munekata, P.E.S.; Ferreira, I.C.F.R.; Barba, F.J. Understanding the potential benefits of thyme and its derived products for food industry and consumer health: From extraction of value-added compounds to the evaluation of bioaccessibility, bioavailability, anti-inflammatory, and antimicrobial activities. Crit. Rev. Food Sci. Nutr. 2019, 59, 2879-2895. [CrossRef]

6. De Carvalho, F.A.L.; Lorenzo, J.M.; Pateiro, M.; Bermúdez, R.; Purriños, L.; Trindade, M.A. Effect of guarana (Paullinia cupana) seed and pitanga (Eugenia uniflora L.) leaf extracts on lamb burgers with fat replacement by chia oil emulsion during shelf life storage at $2{ }^{\circ} \mathrm{C}$. Food Res. Int. 2019, 125, 108554. [CrossRef]

7. Nikmaram, N.; Budaraju, S.; Barba, F.J.; Lorenzo, J.M.; Cox, R.B.; Mallikarjunan, K.; Roohinejad, S. Application of plant extracts to improve the shelf-life, nutritional and health-related properties of ready-to-eat meat products. Meat Sci. 2018, 145, 245-255. [CrossRef]

8. Pateiro, M.; Barba, F.J.; Domínguez, R.; Sant'Ana, A.S.; Mousavi Khaneghah, A.; Gavahian, M.; Gómez, B.; Lorenzo, J.M. Essential oils as natural additives to prevent oxidation reactions in meat and meat products: A review. Food Res. Int. 2018, 113, 156-166. [CrossRef]

9. Lorenzo, J.M.; González-Rodríguez, R.M.; Sánchez, M.; Amado, I.R.; Franco, D. Effects of natural (grape seed and chestnut extract) and synthetic antioxidants (buthylatedhydroxytoluene, BHT) on the physical, chemical, microbiological and sensory characteristics of dry cured sausage "chorizo". Food Res. Int. 2013, 54, 611-620. [CrossRef] 
10. Alirezalu, K.; Pateiro, M.; Yaghoubi, M.; Alirezalu, A.; Peighambardoust, S.H.; Lorenzo, J.M. Phytochemical constituents, advanced extraction technologies and techno-functional properties of selected Mediterranean plants for use in meat products. A comprehensive review. Trends Food Sci. Technol. 2020, 100, 292-306. [CrossRef]

11. Fernandes, R.P.P.; Trindade, M.A.; Lorenzo, J.M.; de Melo, M.P. Assessment of the stability of sheep sausages with the addition of different concentrations of Origanum vulgare extract during storage. Meat Sci. 2018, 137, 244-257. [CrossRef] [PubMed]

12. Munekata, P.E.S.; Rocchetti, G.; Pateiro, M.; Lucini, L.; Domínguez, R.; Lorenzo, J.M. Addition of plant extracts to meat and meat products to extend shelf-life and health-promoting attributes: An overview. Curr. Opin. Food Sci. 2020, 31, 81-87. [CrossRef]

13. El Moein, N.; Mahmoud, E.; Shalaby, E.A. Antioxidant mechanism of active ingredients separated from Eucalyptus globulus. Org. Chem. Curr. Res. 2012, 1, 1-7. [CrossRef]

14. Pereira, V.; Dias, C.; Vasconcelos, M.C.; Rosa, E.; Saavedra, M.J. Antibacterial activity and synergistic effects between Eucalyptus globulus leaf residues (essential oils and extracts) and antibiotics against several isolates of respiratory tract infections (Pseudomonas aeruginosa). Ind. Crops Prod. 2014, 52, 1-7. [CrossRef]

15. Santos, S.A.O.; Villaverde, J.J.; Freire, C.S.R.; Domingues, M.R.M.; Neto, C.P.; Silvestre, A.J.D. Phenolic composition and antioxidant activity of Eucalyptus grandis, E. urograndis (E. grandis $\times$ E. urophylla) and E. maidenii bark extracts. Ind. Crops Prod. 2012, 39, 120-127. [CrossRef]

16. Hasegawa, T.; Takano, F.; Takata, T.; Niiyama, M.; Ohta, T. Bioactive monoterpene glycosides conjugated with gallic acid from the leaves of Eucalyptus globulus. Phytochemistry 2008, 69, 747-753. [CrossRef]

17. Kesharwani, V.; Gupta, S.; Kushwaha, N.; Kesharwani, R.; Patel, D.K. A review on therapeutics application of Eucalyptus oil. Int. J. Herb. Med. 2018, 6, 110-115.

18. Boulekbache-Makhlouf, L.; Meudec, E.; Mazauric, J.P.; Madani, K.; Cheynier, V. Qualitative and semi-quantitative analysis of phenolics in Eucalyptus globulus leaves by high-performance liquid chromatography coupled with diode array detection and electrospray ionisation mass spectrometry. Phytochem. Anal. 2013, 24, 162-170. [CrossRef]

19. Gullón, P.; Gullón, B.; Romaní, A.; Rocchetti, G.; Lorenzo, J.M. Smart advanced solvents for bioactive compounds recovery from agri-food by-products: A review. Trends Food Sci. Technol. 2020, 101, 182-197. [CrossRef]

20. Gullón, P.; Astray, G.; Gullón, B.; Tomasevic, I.; Lorenzo, J.M. Pomegranate peel as suitable source of high-added value bioactives: Tailored functionalized meat products. Molecules 2020, 25, 2859. [CrossRef]

21. Chemat, F.; Abert Vian, M.; Fabiano-Tixier, A.-S.; Nutrizio, M.; Režek Jambrak, A.; Munekata, P.E.S.; Lorenzo, J.M.; Barba, F.J.; Binello, A.; Cravotto, G. A review of sustainable and intensified techniques for extraction of food and natural products. Green Chem. 2020, 22, 2325-2353. [CrossRef]

22. Putnik, P.; Lorenzo, J.; Barba, F.; Roohinejad, S.; Režek Jambrak, A.; Granato, D.; Montesano, D.; Bursać Kovačević, D. Novel food processing and extraction technologies of high-added value compounds from plant materials. Foods 2018, 7, 106. [CrossRef] [PubMed]

23. Putnik, P.; Bursać Kovačević, D.; Režek Jambrak, A.; Barba, F.J.; Cravotto, G.; Binello, A.; Lorenzo, J.M.; Shpigelman, A. Innovative "green" and novel strategies for the extraction of bioactive added value compounds from citruswastes-A review. Molecules 2017, 22, 680. [CrossRef] [PubMed]

24. Burns, J.; Gardner, P.T.; Matthews, D.; Duthie, G.G.; Lean, J.; Crozier, A. Extraction of phenolics and changes in antioxidant activity of red wines during vinification. J. Agric. Food Chem. 2001, 49, 5797-5808. [CrossRef]

25. Magnani, C.; Isaac, V.L.B.; Correa, M.A.; Salgado, H.R.N. Caffeic acid: A review of its potential use in medications and cosmetics. Anal. Methods 2014, 6, 3203-3210. [CrossRef]

26. Žugčić, T.; Abdelkebir, R.; Alcantara, C.; Collado, M.C.; García-Pérez, J.V.; Meléndez-Martínez, A.J.; Režek Jambrak, A.; Lorenzo, J.M.; Barba, F.J. From extraction of valuable compounds to health promoting benefits of olive leaves through bioaccessibility, bioavailability and impact on gut microbiota. Trends Food Sci. Technol. 2019, 83, 63-77. [CrossRef]

27. Roselló-Soto, E.; Martí-Quijal, F.; Cilla, A.; Munekata, P.; Lorenzo, J.; Remize, F.; Barba, F. Influence of temperature, solvent and $\mathrm{pH}$ on the selective extraction of phenolic compounds from tiger nuts by-products: Triple-TOF-LC-MS-MS characterization. Molecules 2019, 24, 797. [CrossRef]

28. Lorenzo, J.M.; Munekata, P.E.S. Phenolic compounds of green tea: Health benefits and technological application in food. Asian Pac. J. Trop. Biomed. 2016, 6, 709-719. [CrossRef] 
29. Domínguez, R.; Zhang, L.; Rocchetti, G.; Lucini, L.; Pateiro, M.; Munekata, P.E.S.; Lorenzo, J.M. Elderberry (Sambucus nigra L.) as potential source of antioxidants. Characterization, optimization of extraction parameters and bioactive properties. Food Chem. 2020, 330, 127266. [CrossRef]

30. Lorenzo, J.M.; Pateiro, M.; Domínguez, R.; Barba, F.J.; Putnik, P.; Kovačević, D.B.; Shpigelman, A.; Granato, D.; Franco, D. Berries extracts as natural antioxidants in meat products: A review. Food Res. Int. 2018, 106, 1095-1104. [CrossRef]

31. Almeida, I.F.; Fernandes, E.; Lima, J.L.F.C.; Valentão, P.; Andrade, P.B.; Seabra, R.M.; Costa, P.C.; Bahia, M.F. Oxygen and nitrogen reactive species are effectively scavenged by Eucalyptus globulus leaf water extract. J. Med. Food 2009, 12, 175-183. [CrossRef] [PubMed]

32. Göktürk Baydar, N.; Özkan, G.; Yaşar, S. Evaluation of the antiradical and antioxidant potential of grape extracts. Food Control 2007, 18, 1131-1136. [CrossRef]

33. Bhuyan, D.J.; Van Vuong, Q.; Chalmers, A.C.; van Altena, I.A.; Bowyer, M.C.; Scarlett, C.J. Microwave-assisted extraction of Eucalyptus robusta leaf for the optimal yield of total phenolic compounds. Ind. Crops Prod. 2015, 69, 290-299. [CrossRef]

34. Amakura, Y.; Umino, Y.; Tsuji, S.; Ito, H.; Hatano, T.; Yoshida, T.; Tonogai, Y. Constituents and their antioxidative effects in Eucalyptus leaf extract used as a natural food additive. Food Chem. 2002, 77, 47-56. [CrossRef]

35. Santos-Ferreira, C.D.; Pereyra, A.; Patriarca, A.; Mazzobre, M.F.; Polak, T.; Abram, V.; Buera, M.P.; Ulrih, N.P. Phenolic compounds in extracts from Eucalyptus globulus leaves and Calendula officinalis flowers. J. Nat. Prod. Resour. 2016, 2, 53-57.

36. Nasr, A.; Khan, T.S.; Huang, S.-P.; Wen, B.; Shao, J.-W.; Zhu, G.-P. Comparison among five Eucalyptus species based on their leaf contents of some primary and secondary metabolites. Curr. Pharm. Biotechnol. 2019, 20, 573-587. [CrossRef]

37. Dezsi, S.; Bădărău, A.S.; Bischin, C.; Vodnar, D.C.; Silaghi-Dumitrescu, R.; Gheldiu, A.-M.; Mocan, A.; Vlase, L. Antimicrobial and antioxidant activities and phenolic profile of Eucalyptus globulus Labill. and Corymbia ficifolia (F. Muell.) K.D. Hill \& L.A.S. Johnson leaves. Molecules 2015, 20, 4720-4734. [CrossRef]

38. Nasr, A.; Saleem Khan, T.; Zhu, G.-P. Phenolic compounds and antioxidants from Eucalyptus camaldulensis as affected by some extraction conditions, a preparative optimization for GC-MS analysis. Prep. Biochem. Biotechnol. 2019, 49, 464-476. [CrossRef]

39. Vázquez, G.; Santos, J.; Freire, M.S.; Antorrena, G.; González-Álvarez, J. Extraction of antioxidants from eucalyptus (Eucalyptus globulus) bark. Wood Sci. Technol. 2012, 46, 443-457. [CrossRef]

40. Celeiro, M.; Lamas, J.P.; Arcas, R.; Lores, M. Antioxidants profiling of by-products from Eucalyptus greenboards manufacture. Antioxidants 2019, 8, 263. [CrossRef]

41. Gullón, B.; Gullón, P.; Lú-Chau, T.A.; Moreira, M.T.; Lema, J.M.; Eibes, G. Optimization of solvent extraction of antioxidants from Eucalyptus globulus leaves by response surface methodology: Characterization and assessment of their bioactive properties. Ind. Crops Prod. 2017, 108, 649-659. [CrossRef]

42. Gullón, B.; Muñiz-Mouro, A.; Lú-Chau, T.A.; Moreira, M.T.; Lema, J.M.; Eibes, G. Green approaches for the extraction of antioxidants from Eucalyptus leaves. Ind. Crops Prod. 2019, 138, 111473. [CrossRef]

43. Xavier, L.; Freire, M.S.; Vidal-Tato, I.; González-Álvarez, J. Recovery of phenolic compounds from eucalyptus wood wastes using ethanol-salt-based aqueous two-phase systems. Maderas Cienc. Technol. 2017, 19, 3-14. [CrossRef]

44. Barba, F.J.; Putnik, P.; Bursać Kovačević, D.; Poojary, M.M.; Roohinejad, S.; Lorenzo, J.M.; Koubaa, M. Impact of conventional and non-conventional processing on prickly pear (Opuntia spp.) and their derived products: From preservation of beverages to valorization of by-products. Trends Food Sci. Technol. 2017, 67, 260-270. [CrossRef]

45. Abdelkebir, R.; Alcántara, C.; Falcó, I.; Sánchez, G.; Garcia-Perez, J.V.; Neffati, M.; Lorenzo, J.M.; Barba, F.J.; Collado, M.C. Effect of ultrasound technology combined with binary mixtures of ethanol and water on antibacterial and antiviral activities of Erodium glaucophyllum extracts. Innov. Food Sci. Emerg. Technol. 2019, 52, 189-196. [CrossRef]

46. Jiang, T.; Zhan, S.; Li, S.; Zhu, Z.; He, J.; Lorenzo, J.M.; Barba, F.J. From 'green' technologies to 'red' antioxidant compounds extraction of purple corn: a combined ultrasound-ultrafiltration-purification approach. J. Sci. Food Agric. 2018, 98, 4919-4927. [CrossRef] 
47. Žlabur, J.Š.; Žutić, I.; Radman, S.; Pleša, M.; Brnčić, M.; Barba, F.J.; Rocchetti, G.; Lucini, L.; Lorenzo, J.M.; Domínguez, R.; et al. Effect of different green extraction methods and solvents on bioactive components of chamomile (Matricaria chamomilla L.) flowers. Molecules 2020, 25, 810. [CrossRef]

48. Tanase, C.; Cosarcă, S.; Muntean, D.L. A critical review of phenolic compounds extracted from the bark of woody vascular plants and their potential biological activity. Molecules 2019, 24, 1182. [CrossRef]

49. Gullón, B.; Lú-Chau, T.A.; Moreira, M.T.; Lema, J.M.; Eibes, G. Rutin: A review on extraction, identification and purification methods, biological activities and approaches to enhance its bioavailability. Trends Food Sci. Technol. 2017, 67, 220-235. [CrossRef]

50. Ameer, K.; Shahbaz, H.M.; Kwon, J.H. Green extraction methods for polyphenols from plant matrices and their byproducts: A review. Compr. Rev. Food Sci. Food Saf. 2017, 16, 295-315. [CrossRef]

51. González, N.; Elissetche, J.; Pereira, M.; Fernández, K. Extraction of polyphenols from Eucalyptus nitens and Eucalyptus globulus: Experimental kinetics, modeling and evaluation of their antioxidant and antifungical activities. Ind. Crops Prod. 2017, 109, 737-745. [CrossRef]

52. Vuong, Q.V.; Hirun, S.; Chuen, T.L.K.; Goldsmith, C.D.; Munro, B.; Bowyer, M.C.; Chalmers, A.C.; Sakoff, J.A.; Phillips, P.A.; Scarlett, C.J. Physicochemical, antioxidant and anti-cancer activity of a Eucalyptus robusta (Sm.) leaf aqueous extract. Ind. Crops Prod. 2015, 64, 167-174. [CrossRef]

53. Luís, A.; Neiva, D.; Pereira, H.; Gominho, J.; Domingues, F.; Duarte, A.P. Stumps of Eucalyptus globulus as a source of antioxidant and antimicrobial polyphenols. Molecules 2014, 19, 16428-16446. [CrossRef] [PubMed]

54. Iyyappan, J.; Balamurali, M.N.; Bhuvaneshwari, R.; Baskar, G.; Seenuvasan, M. Effective extraction of total phenolic compounds bearing anti-obesity activity from Eucalyptus globulus. J. Chem. Pharm. Sci. 2016, 9, 250-255.

55. Bhuyan, D.J.; Vuong, Q.V.; Chalmers, A.C.; van Altena, I.A.; Bowyer, M.C.; Scarlett, C.J. Development of the ultrasonic conditions as an advanced technique for extraction of phenolic compounds from Eucalyptus robusta. Sep. Sci. Technol. 2017, 52, 100-112. [CrossRef]

56. Miranda, I.; Lima, L.; Quilhó, T.; Knapic, S.; Pereira, H. The bark of Eucalyptus sideroxylon as a source of phenolic extracts with anti-oxidant properties. Ind. Crops Prod. 2016, 82, 81-87. [CrossRef]

57. Wong Paz, J.E.; Muñiz Márquez, D.B.; Martínez Ávila, G.C.G.; Belmares Cerda, R.E.; Aguilar, C.N. Ultrasound-assisted extraction of polyphenols from native plants in the Mexican desert. Ultrason. Sonochem. 2015, 22, 474-481. [CrossRef]

58. Fernández-Agulló, A.; Freire, M.S.; González-Álvarez, J. Effect of the extraction technique on the recovery of bioactive compounds from eucalyptus (Eucalyptus globulus) wood industrial wastes. Ind. Crops Prod. 2015, 64, 105-113. [CrossRef]

59. Gharekhani, M.; Ghorbani, M.; Rasoulnejad, N. Microwave-assisted extraction of phenolic and flavonoid compounds from Eucalyptus camaldulensis Dehn leaves as compared with ultrasound-assisted extraction. Lat. Am. Appl. Res. 2012, 42, 305-310.

60. Santos, S.A.O.; Villaverde, J.J.; Silva, C.M.; Neto, C.P.; Silvestre, A.J.D. Supercritical fluid extraction of phenolic compounds from Eucalyptus globulus Labill bark. J. Supercrit. Fluids 2012, 71, 71-79. [CrossRef]

61. Herzi, N.; Bouajila, J.; Camy, S.; Cazaux, S.; Romdhane, M.; Condoret, J.S. Comparison between supercritical $\mathrm{CO}_{2}$ extraction and hydrodistillation for two species of Eucalyptus: Yield, chemical composition, and antioxidant activity. J. Food Sci. 2013, 78. [CrossRef] [PubMed]

62. Kulkarni, A.; Suzuki, S.; Etoh, H. Antioxidant compounds from Eucalyptus grandis biomass by subcritical liquid water extraction. J. Wood Sci. 2008, 54, 153-157. [CrossRef]

63. Paiva, A.; Craveiro, R.; Aroso, I.; Martins, M.; Reis, R.L.; Duarte, A.R.C. Natural deep eutectic solvents-Solvents for the 21st century. ACS Sustain. Chem. Eng. 2014. [CrossRef]

64. Zhao, B.; Xu, P.; Yang, F.; Wu, H.; Zong, M.; Lou, W. Biocompatible deep eutectic solvents based on choline chloride: Characterization and application to the extraction of rutin from Sophora japonica. ACS Sustain. Chem. Eng. 2015, 3, 2746-2755. [CrossRef]

65. Huang, Y.; Feng, F.; Jiang, J.; Qiao, Y.; Wu, T.; Voglmeir, J.; Chen, Z. Green and efficient extraction of rutin from tartary buckwheat hull by using natural deep eutectic solvents. Food Chem. 2017, 221, 1400-1405. [CrossRef] [PubMed]

66. Tomšik, A.; Pavlić, B.; Vladić, J.; Ramić, M.; Brindza, J.; Vidović, S. Optimization of ultrasound-assisted extraction of bioactive compounds from wild garlic (Allium ursinum L.). Ultrason. Sonochem. 2016, 29, 502-511. [CrossRef] 
67. Martínez-Patiño, J.C.; Gullón, B.; Romero, I.; Ruiz, E.; Brnčić, M.; Žlabur, J.Š.; Castro, E. Optimization of ultrasound-assisted extraction of biomass from olive trees using response surface methodology. Ultrason. Sonochem. 2019, 51, 487-495. [CrossRef]

68. Gullón, B.; Gagaoua, M.; Barba, F.J.; Gullón, P.; Zhang, W.; Lorenzo, J.M. Seaweeds as promising resource of bioactive compounds: Overview of novel extraction strategies and design of tailored meat products. Trends Food Sci. Technol. 2020, 100, 1-18. [CrossRef]

69. Araújo, M.; Pimentel, F.B.; Alves, R.C.; Oliveira, M.B.P.P. Phenolic compounds from olive mill wastes: Health effects, analytical approach and application as food antioxidants. Trends Food Sci. Technol. 2015, 45, 200-211. [CrossRef]

70. Nayak, B.; Dahmoune, F.; Moussi, K.; Remini, H.; Dairi, S.; Aoun, O.; Khodir, M. Comparison of microwave, ultrasound and accelerated-assisted solvent extraction for recovery of polyphenols from Citrus sinensis peels. Food Chem. 2015, 187, 507-516. [CrossRef]

71. Pimentel-Moral, S.; Borrás-Linares, I.; Lozano-Sánchez, J.; Arráez-Román, D.; Martínez-Férez, A.; Segura-Carretero, A. Supercritical $\mathrm{CO}_{2}$ extraction of bioactive compounds from Hibiscus sabdariffa. J. Supercrit. Fluids 2019, 147, 213-221. [CrossRef]

72. Montes, A.; Bendel, A.; Kürti, R.; Gordillo, M.D.; Pereyra, C.; Martínez De La Ossa, E.J. Processing naproxen with supercritical $\mathrm{CO}_{2}$. J. Supercrit. Fluids 2013, 75, 21-29. [CrossRef]

73. Herrero, M.; Cifuentes, A.; Ibañez, E. Sub- and supercritical fluid extraction of functional ingredients from different natural sources: Plants, food-by-products, algae and microalgae-A review. Food Chem. 2006, 98, 136-148. [CrossRef]

74. Bimakr, M.; Rahman, R.A.; Taip, F.S.; Ganjloo, A.; Salleh, L.M.; Selamat, J.; Hamid, A.; Zaidul, I.S.M. Comparison of different extraction methods for the extraction of major bioactive flavonoid compounds from spearmint (Mentha spicata L.) leaves. Food Bioprod. Process. 2011, 89, 67-72. [CrossRef]

75. Astray, G.; Gullón, P.; Gullón, B.; Munekata, P.E.S.; Lorenzo, J.M. Humulus lupulus L. as a natural source of functional biomolecules. Appl. Sci. 2020, 10, 5074. [CrossRef]

76. Pereira, C.G.; Meireles, M.A.A. Supercritical fluid extraction of bioactive compounds: Fundamentals, applications and economic perspectives. Food Bioprocess Technol. 2010, 3, 340-372. [CrossRef]

77. Rahmanian, N.; Jafari, S.M.; Wani, T.A. Bioactive profile, dehydration, extraction and application of the bioactive components of olive leaves. Trends Food Sci. Technol. 2015, 42, 150-172. [CrossRef]

78. Ashraf, A.; Sarfraz, R.A.; Mahmood, A.; Din, M.U. Chemical composition and in vitro antioxidant and antitumor activities of Eucalyptus camaldulensis Dehn. leaves. Ind. Crops Prod. 2015, 74, 241-248. [CrossRef]

79. González-Burgos, E.; Liaudanskas, M.; Viškelis, J.; Žvikas, V.; Janulis, V.; Gómez-Serranillos, M.P. Antioxidant activity, neuroprotective properties and bioactive constituents analysis of varying polarity extracts from Eucalyptus globulus leaves. J. Food Drug Anal. 2018, 26, 1293-1302. [CrossRef]

80. Santos, S.A.O.; Vilela, C.; Domingues, R.M.A.; Oliveira, C.S.D.; Villaverde, J.J.; Freire, C.S.R.; Neto, C.P.; Silvestre, A.J.D. Secondary metabolites from Eucalyptus grandis wood cultivated in Portugal, Brazil and South Africa. Ind. Crops Prod. 2017, 95, 357-364. [CrossRef]

81. Gomes, F.; Martins, N.; Barros, L.; Rodrigues, M.E.; Oliveira, M.B.P.P.; Henriques, M.; Ferreira, I.C.F.R. Plant phenolic extracts as an effective strategy to control Staphylococcus aureus, the dairy industry pathogen. Ind. Crops Prod. 2018, 112, 515-520. [CrossRef]

82. Singab, A.N.; Ayoub, N.; Al-Sayed, E.; Martiskainen, O.; Sinkkonen, J.; Pihlaja, K. Phenolic constituents of Eucalyptus camaldulensis Dehnh, with potential antioxidant and cytotoxic activities. Rec. Nat. Prod. 2011, 5, 271-280.

83. Teixeira, A.; Dacunha, D.C.; Barros, L.; Caires, H.R.; Xavier, C.P.R.; Ferreira, I.C.F.R.; Vasconcelos, M.H. Eucalyptus globulus Labill. decoction extract inhibits the growth of NCI-H460 cells by increasing the p53 levels and altering the cell cycle profile. Food Funct. 2019, 10, 3188-3197. [CrossRef] [PubMed]

84. Ganesan, D.; Al-Sayed, E.; Albert, A.; Paul, E.; Singab, A.N.B.; Govindan Sadasivam, S.; Saso, L. Antioxidant activity of phenolic compounds from extracts of Eucalyptus globulus and Melaleuca styphelioides and their protective role on D-glucose-induced hyperglycemic stress and oxalate stress in NRK-49Fcells. Nat. Prod. Res. 2018, 32, 1274-1280. [CrossRef] [PubMed]

85. Jiang, P.; Xiong, J.; Wang, F.; Grace, M.H.; Lila, M.A.; Xu, R. $\alpha$-Amylase and $\alpha$-glucosidase inhibitory activities of phenolic.pdf. J. Chem. 2017, 2017, 1-8. 
86. Moreira, D.; Gullón, B.; Gullón, P.; Gomes, A.; Tavaria, F. Bioactive packaging using antioxidant extracts for the prevention of microbial food-spoilage. Food Funct. 2016, 7, 3273-3282. [CrossRef]

87. Al-Sayed, E.; Singab, A.N.; Ayoub, N.; Martiskainen, O.; Sinkkonen, J.; Pihlaja, K. HPLC-PDA-ESI-MS/MS profiling and chemopreventive potential of Eucalyptus gomphocephala DC. Food Chem. 2012, 133, 1017-1024. [CrossRef]

88. Bhagat, M.; Sharma, V.; Saxena, A.K. Anti-proliferative effect of leaf extracts of Eucalyptus citriodora against human cancer cells in vitro and in vivo. Indian J. Biochem. Biophys. 2012, 49, 451-457.

89. Islam, F.; Khatun, H.; Ghosh, S.; Ali, M.M.; Khanam, J.A. Bioassay of Eucalyptus extracts for anticancer activity against ehrlich ascites carcinoma (EAC) cells in Swiss albino mice. Asian Pac. J. Trop. Biomed. 2012, 2, 394-398. [CrossRef]

(C) 2020 by the authors. Licensee MDPI, Basel, Switzerland. This article is an open access article distributed under the terms and conditions of the Creative Commons Attribution (CC BY) license (http://creativecommons.org/licenses/by/4.0/). 